O eixo e a roda, Belo Horizonte, v.25, n.2, p. 105-126, 2016

\title{
Do conto ao romance: o processo criativo de Lima Barreto entre a forma literária e o suporte
}

\section{From the short story to the novel: Lima Barreto's creative process between the literary form and support}

Elizabeth Gonzaga Lima

Universidade do Estado da Bahia (UNEB), Salvador/Jacobina / Brasil betylyma@gmail.com

Resumo: O artigo objetiva examinar o processo criativo de Lima Barreto em relação à forma literária conto. As anotações esparsas em seu Diário íntimo (1956) apresentam alguns aspectos da construção ficcional de Clara dos Anjos, concebido como conto, folhetim e romance. Os procedimentos relatados pelo escritor lembram, de certa maneira, "A filosofia da composição", de Edgar Allan Poe (1981), ao revelar seu modus operandi na elaboração ficcional. O recorte escolhido, o conto "Clara dos Anjos", foi publicado em revista, migrou para o texto seriado do folhetim e finalizou sua trajetória no formato livro. A análise pretende demonstrar que, no processo criativo desse texto ficcional de Lima Barreto, articula-se o trânsito entre forma literária e suporte, que em última instância fundamenta sua constante experimentação estética. Palavras-chave: Lima Barreto; Clara dos Anjos; conto; forma literária, processo criativo; experimentação estética.

Abstract: This article aims at examining Lima Barreto's creative process in regard to the literary genre of the short story. In his Diário intimo (1956), the sparse notes feature aspects of the fictional piece Clara dos Anjos, conceived as short story, feuilleton and novel. The author's procedures recall, to a certain extent, "The philosophy of composition" 
by Edgar Allan Poe (1981) insofar as they point to the modus operandi to fiction construction. The selected corpus, namely the short story "Clara dos Anjos", was first published in a magazine, subsequently published as feuilleton and finally as a book. The analysis aims at demonstrating that the creative process of this fictional text by Lima Barreto articulated the shift between literary form and support, which ultimately grounds his constant aesthetic experimentation.

Keywords: Lima Barreto; Clara dos Anjos; short story; literary form; creative process, aesthetic experimentation.

Recebido em 23 de maio de 2016.

Aprovado em 5 de agosto de 2016.

\section{A forma literária conto: deslizante e sem leis}

Desde tempos imemoriais, os contos, sejam orais, sejam escritos, fascinam um público cativo deste tipo de narrativa, como na emblemática sedução vivenciada pelo sultão Schariah, das Mil e uma noites. Esta forma literária é considerada uma das mais antigas e dinâmicas da prosa de ficção por adaptar-se às diversas transformações culturais, sociais e estéticas. A volatilidade, como característica intrínseca dessa narrativa, aponta para um aspecto de imprecisão de seus contornos, dificultando definições em virtude de uma interface híbrida que se contamina facilmente por outros gêneros. Tal circunstância propicia a observadores argutos como Mário de Andrade ironizar: "Tanto andam agora preocupados em definir o conto que não sei bem se o que vou contar é conto ou não, sei que é verdade" (ANDRADE, 2015, p. 13).

A observação de Mário de Andrade, ainda que em tom jocoso, revela uma dúvida que tem instigado escritores e teóricos ao empreenderem uma constante busca para compreender a configuração escorregadia desta narrativa curta. Dentre os escritores, destaca-se o norte-americano Edgar Allan Poe, considerado precursor da teoria sobre o conto no século XIX com a resenha de Twice-told tales, de Nathanael Hawthorne, publicada em 1843. Quase um ano depois, Allan Poe escreve um de seus textos de referência, "A filosofia da composição" (1981), 
em que retoma os fundamentos da escrita breve e revela o esquema de composição do poema "O corvo", demonstrando uma atitude moderna, ainda que controversa, ao assumir que o processo criativo não é oriundo da intuição ou do acaso, mas antes é regido pela precisão matemática e pelo intuito de agradar crítica e público. Na construção do procedimento criativo, Poe (1981) considera a relevância da extensão da narrativa curta, seja um poema, seja um conto: "Se alguma obra literária é longa demais para ser lida de uma assentada, devemos resignar-nos a dispensar o efeito imensamente importante que deriva da unidade de impressão" (POE, 1981, p. 912). A unidade de efeito ou de impressão seria necessária para capturar rapidamente a "alma" do leitor, devendo a leitura ser feita de uma única assentada e, como ressaltou na resenha, é preciso levar em consideração a força que deriva da totalidade de uma narrativa curta.

Se Poe (1981, p. 912) entende como essencial em uma narrativa "certo efeito único e singular", o escritor russo Anton Tchekov postula que o conto deve produzir no leitor o "efeito de totalidade" (ANGELIDES, 1995). Em carta de 10 de maio de 1886 a Aleksandr P. Tchekov, o contista enumera aspectos que considera fundamentais para a elaboração de um conto: "1 ausência de palavrório prolongado de natureza políticosócio-econômica; 2 objetividade total; 3 veracidade nas descrições das personagens e dos objetos; 4 brevidade extrema; 5 ousadia e originalidade - fuga dos chavões; 6 sinceridade" (ANGELIDES, 1995, p. 52). Somando-se a esses critérios, o conto não deveria permitir sobras de personagens, tudo que fosse desnecessário deveria ser eliminado.

$\mathrm{Na}$ esteira de Poe e Tchekov, já no século XX, o escritor argentino Júlio Cortázar, em "Alguns aspectos do conto", reconhece, de saída, que não há leis que regem o conto, cabendo, em vez disso, falar de pontos de vista, ou "de certas constantes que dão estrutura a esse gênero tão pouco classificável" (CORTÁZAR, 2006, p. 150). A fim de explicar seu entendimento, o escritor recorre à imagem de duas técnicas que foram absorvidas pela comunicação de massa, o cinema e a fotografia, estabelecendo uma analogia com o romance e o conto:

Enquanto no cinema, como no romance, a captação dessa realidade mais ampla e multiforme é alcançada mediante o desenvolvimento de elementos parciais, acumulativos, que não excluem, por certo, uma síntese que dê o clima da obra, numa fotografia ou num conto de grande qualidade se procede inversamente, isto é, o fotógrafo ou o contista 
sentem necessidade de escolher e limitar uma imagem ou um acontecimento que sejam significativos, que não só valham por si mesmos, mas também sejam capazes de atuar no espectador ou no leitor como uma espécie de abertura (CORTÁZAR, 2006, p. 151).

Essas tentativas de delimitar o conto, perscrutar sua natureza independem de nacionalidades, gostos ou valores. O objeto continua escorregando das mãos de especialistas e de leitores curiosos, cuja recepção do assunto ainda não foi investigada de forma mais verticalizada. Por mais que as abordagens tragam como elemento estruturante o efeito da brevidade, constata-se que o conto se assenta sobre terreno fronteiriço e, provavelmente por este aspecto, venha sendo cercado pela compulsão humana de enquadrar, de buscar origens, de desvendar os segredos da caixa-preta de sua construção. Todavia, quanto mais se tenta cercar este gênero, mais ele escapa - e essa tem sido a sorte dos leitores, a sedução por uma forma literária fugidia, que potencializa seu dinamismo e renovação constante. Nesta perspectiva, o trabalho pretende analisar o processo criativo de Lima Barreto na construção ficcional de Clara dos Anjos, narrativa que surge na forma literária conto e se desdobra em folhetim e romance.

\section{Breve nota sobre o conto na literatura brasileira}

A notícia do conto na literatura brasileira é imprecisa, como denota o comentário de Armando Moreno em A biologia do conto, ao considerar que os primeiros contistas teriam sido "Joaquim Norberto em 1841 com o conto 'As duas órfãs', Justiniano José da Rocha com 'A caixa e o tinteiro' em 1836 ou, em 1837 com 'Um sonho’ Pereira da Silva ou Martins Pena” (MORENO, 1987, p. 446). Em Os precursores do conto no Brasil, Barbosa Lima Sobrinho utiliza o critério histórico, sem estabelecer juízo estético de valor para noticiar a formação do conto literário no Brasil, reunindo nomes como Francisco de Paula Brito, Vicente Pereira de Carvalho, Josino Nascimento Silva, entre outros: "Estamos apenas enumerando poemas, romances, novelas e contos, que apareceram nessa época a que nos reportamos" (LIMA SOBRINHO, 1961, p. 22).

A ficção romântica desponta no Brasil no primeiro quartel do século XIX, comprometida com a instauração do discurso da identidade nacional. Escritores como José de Alencar empreendem 
uma cartografia geográfico-literária do Brasil, tornando o regionalismo uma das características estruturantes de nossa literatura. Já na segunda metade daquele século surge Machado de Assis, um dos maiores expoentes da história da literatura brasileira, desenvolvendo uma prosa de ficção madura e sofisticada para os padrões da época, seja no conto, seja no romance. Entretanto, ainda que escrevesse sob os influxos do romantismo, Machado fugiu ao lugar-comum do regionalismo, oxigenando a representação literária brasileira ao trabalhar linguagem, temas, personagens e narrador com um maior nível de complexidade, inovar com flashes metalinguísticos, manejar com propriedade a ironia, escapar do "instinto de nacionalidade", focalizar a contradição humana. Contos como "O alienista", "Igreja do diabo", "Teoria do medalhão", "Causa secreta" e "A cartomante" justificam a alcunha "Bruxo do Cosme Velho", tal a alquimia ficcional desenvolvida em sua prosa.

No período finissecular e nas primeiras décadas do século XX, emerge um elenco de contistas de estilos diversificados, como Lima Barreto, João do Rio, Monteiro Lobato, Mário de Andrade, que de maneira pulverizada desenvolveram temáticas e estéticas díspares. Mas a que se pode atribuir este crescimento exponencial no número de escritores de contos? A questão não é simples, são diversos fatores combinados. No entanto, é notório que o avanço da imprensa empresarial e a demanda dos leitores por conteúdo abriram espaços nas folhas diárias para esta narrativa curta, que se encaixava muito bem ao formato do jornal. Essa circunstância foi apontada por Tchekov, que enxergava na expansão da imprensa ao longo do século XIX o provável motivo para o aumento da produção de contos. A associação entre imprensa e discurso literário sinaliza para a modernização literária, visto que a evolução das técnicas de impressão delineia, de certa maneira, os caminhos da escrita da literatura naquele contexto (BROCA, 1975).

O suporte jornal se conforma aos fundamentos da narrativa curta apontados por Allan Poe (1981), Tchekov (cf. ANGELIDES, 1995) e Cortázar (2006): brevidade, objetividade e totalidade. O conto passa a dividir espaço com os anúncios, as notícias e as reportagens. Instaura-se uma relação entre as duas linguagens: "A boa forma de informação imita a forma do conto, e a boa forma do conto imita a informação, finge que é pura informação: o conto quer ser notícia de jornal, a notícia de jornal quer ser conto" (GALVÃO, 1983, p. 167). A pertinência da observação da estudiosa pode ser constatada nos contos de João do Rio, cuja escrita 
incorporou os sestros de um repórter em seus dois livros de contos: Dentro da noite, que apresenta um desfile de situações bizarras empreendidas pela elite da Belle Époque na busca desenfreada por experiências sexuais inusitadas; e $A$ mulher e os espelhos, no qual o escritor ficcionaliza uma galeria de mulheres, em sua maioria prostitutas. Não há como negar que a reportagem, gênero de que João do Rio esteve na vanguarda, tornou-se matéria-prima para os contos, daí em alguns momentos o tom jornalístico contaminar a dicção do contista:

Dizem que outros trechos urbanos resistem à civilização normalizadora, mantendo, apesar de tudo, a personalidade. Estávamos num ponto de movimento extraordinário, com iluminação escandalosa dos teatros; por todos os lados, o turbilhão de conduções correndo, buzinando, rolando entre a multidão densa. E, entretanto, a praça mantinha as suas horrendas tradições (RIO, 1995, p. 26).

O estilo de João do Rio atesta a afirmação de Walnice Galvão (1983, p. 171) acerca dessa zona fronteiriça entre o jornalismo e a literatura: "O conto já arremeda o jornal, não mais porque queira parecerse com ele, mas sim porque quer parodiá-lo, maximizar os efeitos dele, tomar os elementos fragmentados do seu discurso para brincar com eles". Nessa esteira da junção das linguagens jornalística e literária, Lima Barreto mostra-se, assim como João do Rio e outros contemporâneos, um prolífico cronista, mesclando a narrativa ficcional ao universo das notícias. Morador do subúrbio de Todos os Santos, andarilho urbano contumaz, compreendia muito bem a cisão da cidade entre suburbanos e "botafoganos", circunstância que terminou inspirando muitas de suas páginas críticas.

\section{Lima Barreto, o suporte e a escrita literária}

Lima Barreto começou muito jovem a colaborar na imprensa. O princípio dos anos 1900 era um momento efervescente para os literatos nas redações dos jornais. Nesse período, o texto literário passou a ser uma espécie de mercadoria que o escritor comercializava com os editores de periódicos. Logo o romancista captou que o suporte jornal poderia proporcionar em sua carreira certa visibilidade e dinheiro rápido, encurtar o caminho para a publicação de um livro, signo de prestígio 
naquele contexto, e ainda promover sua aceitação nas rodas boêmias e nas associações dos homens de letras.

O estudioso e o leitor interessados notarão no conjunto da produção do escritor que a relação com a imprensa é vital para sua vivência no universo literário. A escrita das crônicas sobre a vida da cidade, de forma crítica, por vezes irônica e sarcástica, terminou por permitir ao autor desenvolver um modus operandi de criação, no sentido proposto por Allan Poe (1981). Observa-se no processo criativo de Lima Barreto a articulação entre forma literária e suporte; no entanto, essa relação nunca foi pacífica para o escritor carioca. A princípio sua condição social limitava as possibilidades de colaboração em grandes jornais e a participação em grupos seletos de escritores contratados por editoras renomadas, como Olavo Bilac, Coelho Neto e João do Rio. Em 20 de abril de 1914, em seu Diário íntimo, Lima Barreto desabafa: "Hoje, pus-me a ler velhos números do Mercure de France. Lembro-me bem que os lia antes de escrever o meu primeiro livro. Publiquei-o em 1909. Até hoje, nada adiantei. Não tenho editor, não tenho jornais, não tenho nada" (BARRETO, 1956d, p. 171).

Algumas de suas publicações foram custeadas com recursos próprios. Assim, durante o tempo que separa sua morte da redescoberta de seu acervo por Francisco de Assis Barbosa, e mesmo depois, as reedições de suas obras foram marcadas por problemas de ortografia, de cotejo dos textos, entre outros. Não há aqui nenhuma censura ou crítica aos organizadores ou editores, pois é fato notório o estado precário em que os manuscritos de Lima Barreto foram encontrados. Além disso, os inúmeros periódicos e revistas em que publicou ao longo de sua carreira não mantinham política de conservação da memória com organização de arquivos. Dessa maneira, muitos textos se perderam. Ademais, uma questão estética que ainda desafia os estudiosos que se acercam de sua produção diz respeito à constante hibridação elaborada pelo escritor em contos e crônicas.

Com a organização de sua obra em dezessete volumes por Francisco de Assis Barbosa, pela Editora Brasiliense, em 1956 (daquilo que se pôde resgatar e ordenar), confirmou-se a fertilidade de sua produção, assim como foi possível constatar que diversas anotações de seu diário terminavam se configurando como inspiração para uma crônica ou um conto, como revela este comentário: "Fazer um conto. Pelino, quando vê um sujeito ser fulminado pelo fio elétrico" (BARRETO, 1956d, 
p. 175). A ideia surge de um recorte de jornal sobre a inauguração da iluminação elétrica "em qualquer cidade", onde consta o seguinte aviso: "Perigo! Quem tocar nestes fios cairá fulminado. Pena de prisão e multa para os contraventores." Percebe-se que o mote para o conto se origina de um aviso de teor nonsense veiculado pelo jornal, que encontra a veia criativa e sarcástica do escritor. O comentário do autor é indício de que o Diário íntimo era espaço de tentativas de criação ficcional, numa busca constante de concretizar a escrita, ainda que a esperança de publicação fosse opaca, até pela precariedade do mercado editorial acanhado e elitista, que privilegiava a publicação de escritores consagrados, canonizados e incensados pelos jornais e academias.

Quando se trata de pensar o conto no conjunto da produção de Lima Barreto, "O homem que sabia javanês" talvez seja o mais conhecido do público leitor: adaptado em 1994 para uma série da Rede Globo, em quadrinhos pela Companhia das Letras, consta sempre em livros didáticos e coletâneas. O golpista Castelo, protagonista do conto, representa o arrivismo que emergiu com a Proclamação da República. Outro conto que terminou migrando para a narrativa televisual foi "A nova Califórnia". Ácida crítica à ambição social desmedida, tornou-se base para o enredo da telenovela Fera ferida, de Aguinaldo Silva, em 1992. O conto "Dentes negros cabelos azuis", no conjunto de sua produção contística, destaca-se por ser esteticamente muito bem-acabado, ao ficcionalizar criticamente a intolerância à diferença. Ainda que esses sejam os mais conhecidos do público leitor, o escritor desenvolveu o gênero com fôlego, e algumas vezes o conto se tornava parte de um processo de composição de uma narrativa maior, como atestam os romances Clara dos Anjos e Numa e a Ninfa, ${ }^{1}$ que também foram publicados como contos.

Edgar Allan Poe, em "A filosofia da composição", reflete sobre o quanto seria interessante um autor pormenorizar o passo a passo dos processos de sua composição, mas ressalva:

\footnotetext{
${ }^{1} \mathrm{O}$ conto "Numa e a Ninfa" foi publicado originalmente na página 2 da Gazeta da Tarde, ano III, n. 658, de 3 de junho de 1911, e depois no livro de contos Histórias e sonhos. O folhetim apareceu em $A$ noite em março de 1915. Já o romance foi publicado pela Brasiliense em 1956. Esta obra segue o mesmo percurso criativo de Clara dos Anjos, contudo não foi objeto deste trabalho em função do espaço para o artigo.
} 
Muitos escritores, especialmente os poetas, preferem ter por entendido que compõem por meio de uma espécie de sutil frenesi, de intuição estática; e positivamente estremeceriam ante a ideia de deixar o público dar uma olhadela, por trás dos bastidores, para as rudezas vacilantes e trabalhosas do pensamento, para os verdadeiros propósitos só alcançados no último instante, para os inúmeros relances de ideias que não chegam à maturidade da visão completa, para as imaginações plenamente amadurecidas e repelidas em desespero como inaproveitáveis, para as cautelosas seleções e rejeições, as dolorosas emendas e interpolações; numa palavra, para as rodas e rodinhas, os apetrechos de mudança (POE, 1981, p. 912).

Ainda que Lima Barreto não tenha deixado conscientemente um roteiro de seu processo criativo, este acabou sendo revelado com a descoberta de seus manuscritos, encontrados em tiras de papel, cadernos e bulas de remédio. Ao tomar conhecimento desses e de outros materiais, Assis Barbosa (1988) obteve a autorização da família para adquirir o espólio da produção literária do escritor e em seguida publicá-lo. E com a organização da narrativa autobiográfica, as anotações revelaram uma série de embriões de textos ficcionais, sendo que alguns não foram levados adiante, permaneceram como esboços, e outros, que surgiram como ideias e comentários soltos, terminaram sendo concluídos, como demonstra o processo de construção de Clara dos Anjos.

\section{4 "Clara dos Anjos": o conto}

É possível levantar a hipótese de que essa personagem tenha se tornado para o escritor um desafio criativo que se prolongaria de 1903 a 1922, ano de sua morte. Os primeiros lampejos do projeto se iniciaram com anotações soltas no Diário íntimo em 1903, e depois como texto inacabado em 1904. Em 1919, torna-se conto e é publicado pela Revista América Latina. Em 1920, aparece no livro de contos Histórias e sonhos, publicado pela $A$ Noite, para em seguida, após a morte do escritor em 1922, ser publicado de fevereiro de 1923 a maio de 1924, como folhetim em dezesseis números da Revista Souza Cruz. Já em 1948, a trajetória das edições de Clara dos Anjos ganha sua primeira edição em livro, pela Editora Mérito. 
O nome "Clara" havia aparecido em esboço de um texto que Lima Barreto jamais concluiu. Ela seria mãe de Tito, provável protagonista de uma ficção a ser desenvolvida. Em 1904, aparecem as seguintes notas: "Clara dos Anjos, mulher, mulata, 23 anos", "David Carvalho casa-se mais tarde com Clara, a quem vem conhecer na festa dos Cardosos, na Penha, por ocasião do São João, David, sem ofício certo, é tudo, mais ainda jogador, bêbedo, etc. Dá cabo dos 50 contos de Clara" (BARRETO, 1956d, p. 58).

Em outra anotação, Clara é amigada de um pedreiro de 50 anos, José Portilho, e tem uma filha, Iracema, que foge com um cabo de polícia. Nota-se que o fim reservado a este embrião ficcional é a doença e o envelhecimento de José Portilho, o que termina obrigando Clara a lavar e a engomar para sustentá-lo, enquanto no "terreiro da estalagem em que moram ela canta uma trova qualquer em um belo dia de sol" (BARRETO, 1956d, p. 58), final marcado pela ironia do narrador e pelo conformismo da personagem.

Outras anotações soltas podem ser encontradas no Diário íntimo a respeito da personagem Clara, mas uma em particular chama a atenção do leitor pelo modo sistemático que o escritor elabora as datas para cada acontecimento na vida de Clara. Outro ponto a se ressaltar é que enquanto no conto, no folhetim e no romance não existem cronologias precisas, nestas notas o romancista não somente as especifica, mas as relaciona a acontecimentos:

1903

Época: 1874 a 1905

29

Clara Nasceu 1868.

Morte do pai 1887.

Deflorada 1888 (12 ou 13 de maio).

Dá à luz 1889 .

Deixada 1892.

Casada 1894.

Viúva 1899.

Amigada de novo 1900.

(BARRETO, 1956d, p. 58) 
Pode-se levantar a hipótese, dentre outras possíveis, de que a ideia fixa de Lima Barreto no exercício criativo de Clara seria fruto da sua constante preocupação com a irmã; a personagem, assim, funcionaria como uma espécie de denúncia da condição da mulher de cor em sua sociedade excludente, machista e preconceituosa. É possível inferir esta conjectura no relato de 3 de janeiro de 1904, quando o escritor manifesta insatisfação com o comportamento de Evangelina:

Minha irmã esquecida que como mulata que se quer salvar, deve ter certo recato, uma certa timidez, se atira ou se quer atirar a toda espécie de namoros, mais ou menos mal intencionados (sic) que lhe aparecem. [...] Se minha irmã não fosse de cor, eu não me importaria, mas sendo dá-me cuidados, pois que, de mim para mim, que conheço essa nossa sociedade, foge-me o pensamento ao atinar porque eles as requestam (BARRETO, 1956d, p. 76).

Em 1904, Clara dos Anjos recebe uma versão incompleta que talvez seja a mais melodramática em relação ao conto e ao romance, pois nela o pai de Clara, Manuel dos Anjos, morre já no princípio da história e a mãe, Florência, envelhecida e doente, necessita que a jovem trabalhe em um ateliê de costura para ajudar no sustento da casa. E a caminho do trabalho no centro da cidade ela acaba conhecendo seu sedutor e algoz, nomeado pelo narrador de "rapazola", "adolescente", que a deflora e ainda deixa o caminho livre no quarto de encontros para que um de seus comparsas abuse da moça:

O latagão do outro lado armava o salto para um lado e outro, no fim de enganchá-la. Por fim, de um salto, agarroulhe pela toalha, que ela tinha ao redor do pescoço, que lhe ficou nas mãos. Enfurecido, ele corria da direita para a esquerda, atrás de Clara, saltava a cama, enganava-a, e sempre a rapariga, murmurando pedidos, escapava dos seus botes, com um seguro instinto de conservação. Por fim, já sentindo que as forças lhe iam faltar, Clara pôs-se a gritar por socorro; gritou uma, duas, três, seis vezes, ao fim das quais, violentamente empurrada, a porta do quarto se abriu, e algumas pessoas entraram e levaram os dois até o rondante e daí para a subdelegacia (BARRETO, 1956a, p. 282). 
Em 1919, a Revista América Latina publica o conto "Clara dos Anjos". Não há indicação nas anotações do escritor acerca da razão para o conto ter sido lançado na revista e não em jornal ou livro. É fato conhecido, entretanto, a urgência financeira de Lima Barreto na publicação de seus textos, daí capitalizar a publicação em revistas, levando em consideração a rapidez com que este tipo de periódico colocava a narrativa em cena. Esta circunstância pode ser constatada em seu Diário íntimo, ao confessar que escreveu Numa e a Ninfa em vinte e cinco dias sem copiar ou recopiar nenhum capítulo: "Eu tinha pressa de entregá-lo, para ver se o Marinho me pagava logo, mas não foi assim e recebi o dinheiro aos poucos. Escrevi-o em outubro de 1914. O Marinho era diretor de $A$ Noite" (BARRETO, 1956d, p. 182).

Se o procedimento composicional do "efeito único e singular" defendido por Allan Poe (1981) para uma narrativa curta for observado no conto "Clara dos Anjos", as primeiras linhas não propiciam este efeito, isto é, não fisgam rapidamente o leitor, pois de saída o narrador apresenta a descrição de alguns tipos que constroem a paisagem humana do conto. Estas personagens não ocupam nenhuma função direta ou significante e são apresentadas pelo narrador como moradores locais: Sr. Nascimento, da venda, Mr. Sharp, pastor protestante, J. Amarante, o poeta. A descrição funciona mais para situar o leitor em relação à ambientação do local, o subúrbio do Rio de Janeiro. Contemporaneamente este espaço escolhido para desenrolar o conto não causaria surpresa ao público leitor, mas em fins de século XIX o subúrbio não era o local preferido de romancistas e contistas para desenvolver seus enredos, pois representava as margens, as franjas da cidade do Rio, que o poder público queria ocultar. Esse local serviu como "refúgio de infelizes", na expressão de Lima Barreto em "Clara dos Anjos", no período em que a cidade vivenciou o chamado "Bota-abaixo", quando transformações arquitetônicas radicais empurraram os mais pobres que viviam em cortiços e freges para as localidades mais afastadas, formando-se assim o subúrbio, embrião da favela carioca. Ao utilizar o subúrbio como espaço literário, ao representálo ficcionalmente, Lima Barreto estabeleceu um corte na literatura do período e possivelmente na literatura brasileira, pois este procedimento era diferente do de seus contemporâneos, que preferiam os casarões de Botafogo e as ruas do centro, como a rua do Ouvidor. Assim, o autor de Policarpo Quaresma tentava iluminar a zona de sombra no espaço suburbano que o brilho da Belle Époque carioca buscava ofuscar. 
Ainda que seja uma ficção curta, o conto pode apresentar zonas fronteiriças com outras formas literárias. Aquela que se sobressai nesta narrativa é a crônica, em sua preferência por trazer cenas aparentemente banais: "A rua desenvolvia-se no plano e quando chovia, encharcava que nem em um pântano, entretanto era povoada e dela se descortinava um lindo panorama de montanhas que pareciam cercá-la de todos os lados, embora a grande distância. Tinha boas casas a rua" (BARRETO, 1956b, p. 180). No texto inacabado de 1904, em quatro capítulos, o autor desloca Clara do subúrbio para o centro da cidade. Já no conto de 1919, o desenrolar do drama limita-se à casa dos pais, Joaquim e Engrácia dos Anjos. Um olhar mais pragmático para este procedimento demonstrará que a descrição não traz, a princípio, nenhuma contribuição relevante para o argumento. No entanto, este conto obedece a um dos critérios estabelecidos pelos analistas desta forma literária, como Júlio Cortázar (2006, p. 151): "o conto parte da noção do limite, e, em primeiro lugar, do limite físico".

Um dos critérios mais conhecidos e citados do texto de Cortázar (2006, p. 152) é uma analogia esportiva para ilustrar o efeito instantâneo que o conto pode suscitar no leitor: "nesse combate apaixonante que se trava entre o texto e o leitor, o romance ganha sempre por pontos, enquanto que o conto deve ganhar por knockout". O knockout no leitor do conto de "Clara dos Anjos" vai se estabelecer com a chegada da personagem Júlio Costa. Modinheiro afamado nas vizinhanças, passa a frequentar a casa de Clara e é tomado pelo desejo libidinoso pela doce jovem, que em sua inocência e puerilidade não percebe o que estava brotando naquele instante: "Apresentado aos donos da casa e à filha, ninguém notou o olhar guloso que deitou para os seios empinados de Clara [...] não deixava de devorar com os olhos os bamboleios de quadris de Clarinha, quando dançava" (BARRETO, 1956b, p. 184). Economizando situações intermediárias, o autor logo estabelece a aproximação entre Júlio Costa e Clara. O encontro na janela soa aparentemente fortuito, quando o modinheiro passa em frente à casa da família após entrar no círculo dos comensais do patriarca Joaquim dos Anjos. No entanto, fica evidente para o leitor que está em curso um jogo de sedução de um homem experiente e mau caráter e uma adolescente cheia de sonhos e pensamentos românticos: "foram pequenas frases, galanteios trocados às escondidas, para afinal vir a fatídica carta. Ela recebeu, meteu-a no seio 
e, ao deitar-se leu-a sob a luz da vela, medrosa e palpitante" (BARRETO, 1956b, p. 186).

A missiva é elemento dos mais simbólicos na ficção do século XIX, especialmente nos folhetins, que exploravam este artifício para armar conflitos entre amantes separados por questões sociais ou conjugais. As palavras de Júlio na carta trouxeram sensações até então desconhecidas para Clara: "Ele falava com tanta paixão... ofegava, suspirava, chorava, e os seus seios duros estouravam de virgindade e de ansiedade de amar" (BARRETO, 1956b, p. 187). Nem a fama de conquistador e os comentários de que já havia deflorado algumas moças negras da vizinhança, nem a vigilância constante de seus pais levaram Clara a duvidar das palavras de Júlio ou não aceitar a sedução que se tornava quase um cerco.

Em outra carta chorosa, Júlio relata que a mãe tinha descoberto o romance e insinua: "confessei tudo a mamãe que lhe amava muito e fazia por você as maiores violências [...] Pense bem e veja se estás resolvida a fazer o que lhe pedi na última cartinha" (BARRETO, 1956b, p. 189). Depois de aquiescer aos pedidos de Júlio, Clara passa a recebêlo em seus aposentos durante noites seguidas e "um belo dia, Clara sentiu alguma coisa de estranho no ventre" (BARRETO, 1956b, p. 190). Júlio vai diminuindo as visitas aos aposentos da romântica Clara, às cantorias de Joaquim dos Anjos aos domingos e, por fim, desaparece. Depois de Engrácia descobrir a gravidez, Clara propõe antes de contar ao pai conversar com a mãe de Júlio para pedir que ele se casasse com ela. Recebida com estranheza na casa do sedutor, no meio da conversa é surpreendida pela rispidez de Inês: "- Ora esta! Você não se enxerga! Você não vê mesmo que meu filho não é para casar com gente da laia de você!" (BARRETO, 1956b, p. 191). As palavras da mãe de Júlio funcionam para Clara como o pano que cai, a percepção da diferença, entendida como inferioridade, atingindo a protagonista com a dor da consciência de si em um mundo hostil.

Segundo Ricardo Piglia em Formas breves, "o conto é construído para revelar artificialmente algo que estava oculto. Reproduz a busca sempre renovada de uma experiência única que nos permite ver, sob a superfície opaca da vida, uma verdade secreta" (PIGLIA, 2004, p. 93). Em "Clara dos Anjos", o que estava oculto para a protagonista era sua visceral inferioridade social, ocultada por sua alienação e pelos cuidados inúteis de seus pais, que impediram a jovem de conhecer a realidade 
brutal dos preconceitos que impregnavam a sociedade e produziam marcas indeléveis em sua existência. A "verdade secreta" a que alude Piglia (2004) instaura nesse conto uma espécie de reconhecimento, fator trágico enfrentado por Clara: "Foi ao encontro da mãe. Não lhe disse nada; abraçou-a chorando. A mãe também chorou e, quando Clara parou de chorar, entre soluços, disse: - Mamãe, eu não sou nada nesta vida" (BARRETO, 1956b, p. 191).

Piglia (2004, p. 90) observa em suas teses sobre o conto que este tem "caráter duplo" e é "um relato que encerra um relato secreto". Em "Clara dos Anjos", o relato secreto mostra-se evidente ao leitor, mas não para a personagem, isto é, a protagonista seria seduzida e enganada pela alienação existencial, alimentada pelo som mavioso e romântico das modinhas e pela crença no amor idealizado. O narrador tece a trama acentuando as diferenças entre ela e o sedutor Júlio Costa, este com atitudes ardilosas, dominando o jogo de sedução, enquanto Clara, absorta pela paixão, não percebia que outro relato se tecia paralelamente, ou seja, a ilusão amorosa de mais outra jovem negra vítima de Júlio Costa.

\section{Clara dos Anjos: o folhetim e o romance}

Se o conto busca a objetividade, a brevidade e o efeito de intensidade, o folhetim se estende no tempo, com as publicações fatiadas nos jornais e revistas. Esses suportes têm, como processo técnico, forma e fins diferenciados. Enquanto no suporte jornal o folhetim conta com a recepção imediata e diária do leitor, na revista, a distância temporal entre um número e outro termina por afetar essa recepção.

Com a expansão dos meios de comunicação e o aumento do número de alfabetizados no Brasil, os romances em folhetim, assim como na França, obtiveram uma trajetória de sucesso entre leitores ao longo de muitos anos e possibilitaram às classes populares o acesso à leitura literária, o que antes era privilégio de classes mais abastadas. Contudo, é necessário ressaltar que o interesse popular por esse tipo de texto também foi despertado em virtude das inovações estéticas dessa forma ficcional, que privilegiava o melodramático, mesclado a um tom mais divertido e um enredo mais leve (MEYER, 2006). Por sua vez, os escritores deveriam cumprir as exigências do editor no que tangia ao espaço gráfico e comercial dos periódicos. $\mathrm{O}$ folhetim, fruto das demandas do jornal, convertia-se em mercadoria, e os escritores negociavam seus 
textos, que eram submetidos por semanas ou meses ao público leitor. Dependendo da recepção, o escritor teria mais algum tempo de fama e de trabalho remunerado.

Machado de Assis, em sua crônica "Folhetinista", considera que o folhetim nasceu do jornal. Assim, a princípio um jornalista, o folhetinista caracteriza-se como "a fusão admirável do útil e do fútil. O parto curioso e singular do sério, consorciado com o frívolo" (ASSIS, 2013, p. 44). Já Lima Barreto (1956f, p. 151), com sua verve ácida, declarava: "Não sei o que tem o tal gênero folhetim de tão estritamente atual, do momento, do minuto em que é escrito que, passado esse fugace instante, rançam (sic) logo e perdem o sabor. Considerem que eu já fiz, faço e farei folhetins..."

Apesar do tom crítico, praticamente o conjunto da produção literária de Lima Barreto foi publicado como folhetins: Recordações do escrivão Isaías Caminha saiu nos quatro números da Revista Floreal, entre 1907-1908; Triste fim de Policarpo Quaresma foi publicado no Jornal do Comércio entre 11 de agosto e 10 de novembro de 1911; o periódico A Noite levou a público Numa e a Ninfa de 15 de março a 26 de julho de 1915; e Clara dos Anjos foi publicado de fevereiro de 1923 a maio de 1924 na Revista Souza Cruz, logo após a morte de Lima Barreto. Este último já deveria ter ido a lume em 1922, pois em 7 de janeiro do mesmo ano, no Semanário $A B C$, o escritor informara que havia começado o romance Clara dos Anjos e prometera ao amigo Herbert Moses “publicar na Revista Souza Cruz" (BARRETO, 1956e, p. 171), mas terminou publicando "O carteiro", primeiro capítulo da obra, na Revista Mundo Literário, em maio de 1922, anunciado como página inédita do romance.

A publicação de Clara dos Anjos na Revista Souza Cruz, de fevereiro de 1923 a maio de 1924, tornou-se uma homenagem a Lima Barreto, que havia morrido em novembro de 1922. O formato folhetim não seguia nesta publicação a tradição do texto fatiado no jornal. Como a revista tinha periodicidade mensal, a narrativa não contava com uma recepção imediata por parte do leitor. Tratava-se, na verdade, de um romance no formato de folhetim, com a seriação de capítulos e o tradicional "continua". No conteúdo vislumbram-se componentes folhetinescos, com tintas mais carregadas no tom melodramático, típico deste gênero textual, como a paixão desmedida de Clara dos Anjos por Cassi Jones, a vingança de Cassi ao assassinar Marramaque, a trama urdida por Cassi para conquistar Clara com intuito sexual, a fuga do 
vilão, a humilhação de Clara diante da família do pilantra, a figura trágica e melancólica do poeta Leonardo Flores e a morte violenta do padrinho de Clara. Além desses, outros ingredientes folhetinescos típicos não faltam em Clara dos Anjos, como a virgem violada e abandonada depois da gravidez.

É possível conjecturar que Lima Barreto visava publicar a narrativa em folhetim, em virtude de suas constantes colaborações em revistas que demandavam esse tipo de texto, daí ser possível vislumbrar que o suporte, nesse caso, a revista, estabelecia uma relação direta com a forma desenvolvida pelo escritor, haja vista as diversas tentativas de elaborar Clara dos Anjos, replicando no processo criativo a própria construção do folhetim, com idas e vindas. Nota-se ainda no texto a presença de aspectos típicos do folhetim, como os elencados por Meyer (2006): "realista-sentimental" e "judiciário-policialesco". No entanto, a narrativa opera uma ruptura com o folhetim no que diz respeito ao final. Tradicionalmente o folhetim premia os bons, castiga os maus e o desenlace converge para final feliz; porém, em Clara dos Anjos não há prêmio nem castigo. Cassi trama, comete assassinato, abusa sexualmente de mulheres, mas consegue fugir ileso. Clara é iludida, abusada e termina grávida, humilhada e sem perspectivas de futuro. Enquanto no conto as pinceladas rápidas não permitem ao leitor perceber de modo mais significativo o efeito do melodrama, no folhetim o final arrasta-se, terminando por ressaltar ainda mais o tom dramático.

Em 1948, Clara dos Anjos assume a forma de romance no suporte livro pela Editora Mérito. No conjunto dos romances de Lima Barreto, Clara é a única protagonista mulher, duplo feminino, por assim dizer, do jovem Isaías Caminha, vítima da ilusão dos acenos do poder e da vontade individual em uma sociedade sob a égide da Ordem e do Progresso. Mas enquanto a trajetória romanesca de Isaías converge para o sofrido aprendizado e a adaptação ao ambiente externo, Clara sucumbe à hostilidade do meio.

Depois de décadas de romances rurais, regionalistas ou do cesto de costura dos casarões da corte, Lima Barreto desenvolve o romance urbano ou, mais especificamente, suburbano, espaço escolhido para fazer transitar uma galeria de personagens até então invisibilizados pela literatura brasileira do período, como violeiros, capangas, pequenos servidores públicos, poetas fracassados, jovens mulatas iludidas. 
O romance é uma forma literária mais elástica, podendo abrigar outros formatos sem perder sua essência. Igualmente, o gênero romance é sensível aos movimentos históricos e sociais, incorporando esteticamente as características culturais e sociais do contexto que representa. $\mathrm{Na}$ experimentação empreendida por Lima Barreto em sua produção, o romance configura-se como uma forma mais propícia ao processo criativo.

De acordo com Marthe Robert (2007, p. 14), o romance pode lançar mão da descrição, da narração, desenvolver simultaneamente "fábula, história, apólogo, idílio, crônica, conto, epopéia", e finaliza: "nenhuma prescrição, nenhuma proibição vem limitá-lo na escolha de um tema, um cenário, um tempo, um espaço" (ROBERT, 2007, p. 14). A concepção ficcional última de romance para Clara dos Anjos permitiu a Lima Barreto desenvolver tramas paralelas, como as de Marramaque, Lafões, Leonardo Flores e Cassi Jones. Enquanto o conto apresenta rapidamente o sedutor de Clara e a trama para conquistá-la, o romance aprofunda essas questões, tecendo aspectos dramáticos que envolvem violência, assassinato, traições e mentiras. O drama social se amplia na consciência coletiva de Clara - "Nós não somos nada nesta vida" (BARRETO, 1956c, p.196) -, e não mais na consciência particular, como expressa no conto - "Mamãe, eu não sou nada nesta vida" (BARRETO, 1956b, p. 191).

De certa maneira, Lima Barreto instaura uma espécie de determinismo, procedimento caro ao romance naturalista do século XIX, ao criar uma personagem sem força para reagir às condições determinantes da sociedade, tendo como foco estruturante a questão étnica. A condição da mulher de cor, por um lado, e pobre e suburbana, por outro, potencializa ao máximo o preconceito em relação à jovem Clara. Nessa perspectiva determinista, a própria figura de Cassi Jones é movida pelo desejo sexual camuflado em conquista amorosa. É possível que esta escolha do escritor pelo efeito do determinismo sobre o comportamento da protagonista tenha diminuído a força ficcional e romanesca de Clara dos Anjos, que, mesmo tendo sido sua criação mais extensa temporalmente, ficou aquém de Isaías Caminha e Policarpo Quaresma. O conto, pela extensão, não propicia ao leitor perceber as nuanças de elaboração da protagonista, envolta num torvelinho de emoções que a eleva com um suposto amor correspondido e a rebaixa diante da crua realidade. 


\section{Considerações finais: $O$ drama da vida e a trama da ficção}

Roger Chartier (2002) defende que cada suporte estabelece a maneira de ler, e em última análise, a forma como a escrita se desenvolve. Desta perspectiva, depreende-se que existe uma relação intrínseca entre literatura e os suportes de publicação, pois a materialidade implica em diferentes práticas leitoras. O jornal, por exemplo, é descartável; as revistas ficam a meio caminho entre a fugacidade e a perenidade, ao se tornarem objeto de colecionadores; o livro, por sua vez, carrega a aura do prestígio e da imortalidade. É provável que, com base nessas concepções, os escritores desenvolvam seus textos mirando na relação entre o suporte e o processo de criação da forma literária.

No ambiente das redações Lima Barreto também construiu sua literatura. Os caminhos estéticos e a escolha de qual forma literária desenvolver tornaram-se um desafio para o escritor, que se mostrava indiferente a princípio: "Qualquer gênero servia. Estaria possuído da ânsia de produzir, de realizar alguma coisa de imediato" - revela Francisco de Assis Barbosa (1988, p. 122). Mas logo ele compreendeu que a porta de entrada para a carreira literária seria o suporte jornal. E para alcançar este objetivo, iniciou fazendo reportagens. Segundo Beatriz Resende (1999), em 28 de abril de 1905 surgiu pela primeira vez, no jornal $O$ Correio da Manhã, um texto de Lima Barreto, com uma série de reportagens sobre escavações que a Prefeitura do Rio de Janeiro realizava no Morro do Castelo. Nesta primeira publicação já desponta o estilo e o modus operandi do escritor, a construção de um texto que alia reportagem, folhetim e crônica da cidade. Ainda segundo Resende (1999), a publicação de folhetins e reportagens no jornal comprova que este suporte se configurou como plataforma para os experimentos de jovens escritores que almejavam uma carreira literária. Naquele espaço tornava-se possível explorar a crônica, o conto, o folhetim e a reportagem, por vezes, com uma forma alimentando a outra, tornando, assim, o jornal um veículo imprescindível para construir a base de uma carreira literária naquele período entre fins do século XIX e início do XX.

Nessa perspectiva de experimentação estética, levando em consideração os suportes, o escritor carioca tornou o projeto de Clara dos Anjos matéria-prima para testar as possibilidades da narrativa. Partindo de anotações soltas no Diário íntimo, seguidas de uma versão incompleta em 1904, o desenvolvimento do conto sofre alterações 
significativas em 1919, como a troca dos nomes dos pais de Clara - de Manuel para Joaquim, de Florência para Engrácia. Uma personagem central na trama, o violeiro sedutor, que no texto inacabado é denominado de "adolescente", ganha o nome de Júlio Costa e apresenta-se com mais idade, mas a essência pilantra permanece. No texto anterior ao conto, Clara e o "rapazola" têm seus encontros em um casebre no centro da cidade; no conto, nos aposentos de sua casa, sem que ninguém os ouça ou veja. Na versão de 1904, a última cena transcorre em uma delegacia, com Clara denunciando o ataque do comparsa do "adolescente"; no conto, a protagonista, depois de ser humilhada pela mãe de Júlio, reconhece seu lugar de subalternizada naquela sociedade.

Em "A filosofia da composição", Poe revela que, ao escrever, primeiro se deve almejar um efeito, depois buscar o tom e o acontecimento para auxiliar na construção do efeito. No caso da elaboração de Clara, ainda que Lima Barreto não tenha revelado de maneira mais explícita seus processos, as anotações do Diário íntimo permitem ao leitor perceber que a essência da história da personagem já tinha sido conhecida, isto é, uma vida marcada pelo drama pessoal e social. $\mathrm{O}$ efeito a alcançar residia em sacudir o leitor, em tom de denúncia, chamando sua atenção para os abusos sofridos por uma mulher de cor naquela sociedade, sem chance de reação e sem apoio. Desde as primeiras anotações, é possível observar a evidente intencionalidade de provocar o público leitor com um tema espinhoso e rejeitado por parte da sociedade brasileira do século XX.

Clara dos Anjos não é a melhor obra da lavra romanesca de Lima Barreto. O que torna instigante essa produção é observá-la tendo em vista o processo de construção criativa. Para isso é necessário contrapor as formas do conto, do folhetim e do romance, a fim de compreender o modus operandi do escritor. A trajetória deste texto demonstra que ele era caro a Lima Barreto, em particular por nunca ter conseguido levar a cabo o projeto da história da escravidão negra no Brasil. Por meio da narrativa de Clara dos Anjos ele consegue expor os efeitos nefastos dessa tragédia no país, parte também de sua história pessoal, que naturalmente penetrava o seu universo ficcional, pois, como assinalou Piglia (2004, p. 103): "Todas as histórias do mundo são tecidas com a trama de nossa própria vida".

Durante o período em que Lima Barreto desenvolveu as narrativas de Clara dos Anjos, relatos paralelos construíram, ao longo de quase dezoito anos, o drama de Clara e o drama do processo criativo do escritor, 
que terminou por incorporar um forte componente humano que não se restringiu ao conto, mas se expandiu no folhetim e no romance, pois a face dinâmica da literatura permite pensar a partir do que existe, mas também daquilo que se anuncia por meio da imaginação.

\section{Referências}

ANDRADE, Mário de. Contos novos. Rio de Janeiro: Nova Fronteira, 2015.

ANGELIDES, Sophia. A. P. Tchekov: cartas para uma poética. São Paulo: EDUSP, 1995.

ASSIS, Machado de. Crônicas escolhidas. Organização de John Gledson. São Paulo: Companhia das Letras, 2013.

BARBOSA, Francisco de Assis. A vida de Lima Barreto. 7. ed. Belo Horizonte: Itatiaia; São Paulo: EDUSP, 1988.

BARRETO, Lima. Clara dos Anjos. (Primeira versão incompleta). In: . Diário íntimo. São Paulo: Brasiliense, 1956a.

BARRETO, Lima. Clara dos Anjos. In: . Histórias e sonhos. São Paulo: Brasiliense, 1956b.

BARRETO, Lima. Clara dos Anjos. São Paulo: Brasiliense, 1956c.

BARRETO, Lima. Diário íntimo. São Paulo: Brasiliense, 1956d.

BARRETO, Lima. Marginália. São Paulo: Brasiliense, 1956e.

BARRETO, Lima. Vida urbana. São Paulo: Brasiliense, $1956 f$.

BROCA, Brito. A vida literária no Brasil-1900. 3. ed. Rio de Janeiro: José Olympio, 1975.

CHARTIER, Roger. Os desafios da escrita. Tradução de Fulvia M. L. Moretto. São Paulo: Unesp, 2002.

CORTÁZAR, Júlio. Valise de cronópio. Tradução de David Arrigucci Jr. e João Alexandre Barbosa. São Paulo: Perspectiva, 2006.

GALVÃO, Walnice Nogueira. Cinco teses sobre o conto. In: et al. O livro do Seminário: ensaios Bienal Nestlé de Literatura Brasileira. São Paulo: L R Editores, 1983. 
LIMA SOBRINHO, Barbosa (Org.). Os precursores do conto no Brasil. Rio de Janeiro: Civilização Brasileira, 1961. (Panorama do Conto Brasileiro, 1).

MEYER, Marlyse. Folhetim: uma história. São Paulo: Companhia das Letras, 2006.

MORENO, Armando. A biologia do conto. Coimbra: Almedina, 1987.

PIGLIA, Ricardo. Formas breves. Tradução de José Marcos Mariani de Macedo. São Paulo: Companhia das Letras, 2004.

POE, Edgar Allan. A filosofia da composição. In: . Ficção completa: poesia e ensaios. Tradução de Oscar Mendes e Milton Amado. Rio de Janeiro: Nova Aguilar, 1981.

RESENDE, Beatriz. Introdução. In: BARRETO, Lima. Os subterrâneos do Morro do Castelo. Rio de Janeiro: Dantes, 1999.

RIO, João do. A mulher e os espelhos. Rio de Janeiro: Secretaria Municipal de Cultura, Dep. Geral de Doc. Inf. Cultural, Divisão de Editoração, 1995. (Biblioteca Carioca).

ROBERT, Marthe. Romance das origens, origens do romance. Tradução de André Telles. São Paulo: Cosac Naify, 2007. 